Medal of the American Academy of Arts and Sciences in 1902, the Hughes Medal of the Royal Society in 1916, the Kelvin Medal of British engineering institutions in 1924, the Franklin Medal of the Franklin Institute in 1925, and the Faraday Medal of the Institution of Electrical Engineers in 1927. He died on March 13, 1937.

\section{Sir Isaac Bayley Balfour (1853-1922)}

ONE of the greatest botanists of his day, Isaac Bayley Balfour was born in Edinburgh a century ago, on March 31, 1853, the second son of John Hutton Balfour. Educated at the Edinburgh Academy and University, he graduated B.Sc. in 1873 , D.Sc. in 1875 , M.B. in 1877, and M.D. in 1883. His medical training was interrupted by his appointment in 1874 as botanist to the Royal Society's expedition to Rodriguez Island to observe the transit of Venus, and by a visit five years later to the oceanic island of Socotra to collect plants. After studying with Julius von Sachs at Würzburg and with Anton de Bary at Strassburg, he was appointed professor of botany in the University of Glasgow in 1879, and in 1884 Sherardian professor of botany at Oxford. In 1888 he was called to Edinburgh to fill the three posts which his father, 'Woody Fibre', had held-professor of botany in the University, keeper of the Royal Botanic Garden, and Queen's botanist in Scotland-.. and by a remarkable coincidence he occupied these positions for the same length of time as his father had done, namely, thirty-four years. In each of the universities which he served he was destined to find a department sadly in need of reorganization. At Glasgow he introduced the practical laboratory teaching initiated by his father at Edinburgh a generation earlier. He made Edinburgh an important horticultural centre. No man knew Scotland botanically as well as he did. His most substantial published work, "Botany of Socotra" (1888), includes descriptions of some three hundred new species found in that island. While at Oxford, he persuaded the Clarendon Press to publish the Annals of Botany and also a series of translations of foreign botanical works, under his editorship. Recipient of many honours, he was elected Fellow of the Royal Society in 1884, received the Linnean Medal in 1919, and was created K.B.E. in 1920. He died at Haslemere on November 30,1922 .

\section{Adult Education at Leeds: Dr. S. G. Raybould}

A NEw chair, that of adult education, has been instituted in the University of Leeds, and Dr. S. G. Raybould, at present head of the Department of Adult Education and Extra-Mural Studies and director of extra-mural studies in the University, has been appointed to fill it, with effect from October 1 next. Dr. Raybould graduated from the University of London in 1933, taking his Ph.D. in 1951, and until the end of 1935 was engaged in teaching in schools and part-time work in adult education. $\mathrm{He}$ then obtained an appointment in the University of Leeds as staff tutor, and in 1946 was promoted to be director of extra-mural studies, becoming head of the Adult Education Department five years later. He is at present a member of the Joint Advisory Council of the B.B.C. and of the Central Advisory Council for Education (England), as well as being vice-president of the Workers' Educational Association and deputy chairman of the Central Committee for Adult Education in H.M. Forces. Dr. Raybould's publications include a book on "The English Universities and Adult Education", a Unesco publication, and a number of articles on education.

\section{British Steel Castings Research Association}

A NEW research association has been recently formed in place of the Research and Development Division of the British Steel Founders' Association, and it will be known as the British Steel Castings Research Association. Mr. J. F. B. Jackson, who, as director of research to the British Steel Founders' Association, has had the responsibility for organizing and building up its Research and Development Division since its formation in 1949, has been appointed director of the new Association. The chairman of council is Mr. F. N. Lloyd, and Mr. R. Barber is the secretary. Being derived from an organization that is already three years old and has an active programme of research in hand, the new Association starts off on a good footing. Besides the investigations being carried out at its own research station, work is being done in conjunction with the many well-equipped research laboratories and plant of industrial concerns, and it is also being sponsored in the universities. Thus during the past three years research has ranged over a wide field of steel-casting science and foundry technology, and has included an important series of projects relating to industrial health and to foundry dust suppression ; in this latter connexion, work at the Dust Research Station in Sheffield, which has been in operation since mid-1951, is of particular importance. At the University of Durham and at the Imperial College of Science and Technology, London, essential basic results relating to the mechanism of the freezing of steel in refractory moulds are being obtained, and at the University of Cambridge work on the metal penetration problem and towards the improvement of surface finish in steel castings has continued since 1950. Thus, in general, the formation of this new Research Association represents an important development for a country which is renowned for its steel-making, and we may expect results which will be of vital use to the engineering industry as a whole.

\section{Transliteration of Cyrillic Script}

THE policy of laissez faire in the transliteration of Cyrillic script leads to the same name being spelt Yachevskii and Jarevskij and Yachewsky. This sort of thing obviously causes confusion in bibliographies, and the Royal Society has done a good service by publishing a pamphlet on "The Transliteration of Russian, Serbian and Bulgarian for Bibliographical Purposes" (from the Royal Society, Burlington House, Piccadilly, London, W.1; pp. 16; 1s.). The pamphlet contains tables with the recommended transliteration of Cyrillic to English and English to Cyrillic. The recommendations are agreed by the British Academy and the Royal Society and they are carefully annotated. The only disappointment (and it is an inevitable one) is that the alphabet used in English-speaking countries is not flexible enough to imitate all the sounds of the Cyrillic alphabets; and so we have to fall back on $\hat{e}, \breve{e}, \bar{i}, \grave{i}$, and so on. One hopes that other countries which use the same alphabet as in English will adopt the recommendations.

\section{Harwell Isotope School}

OWING to the continually growing use of radioactive isotopes throughout the world-British sales 